\title{
The Influence of Transformational Leadership Style on Job Satisfaction and Organizational Commitment
}

\author{
Tiara Puspa ${ }^{\bowtie}$, Retno Sari Murtiningsih, Adella Cirealkita, Adillah Dzata Amani \\ Ghea Dwi Fuzi Lestari, Tyas Widyanti \\ Universitas Trisakti, Jakarta \\ e-mail: tiara.puspa@trisakti.ac.id
}

\section{Abstract}

The purpose of this research was to analyze the influence of Transformational Leadership Style on Job Satisfaction and Organizational Commitment. The design of this research used primary data obtained by distributing questionnaires to 147 respondents, the employees of the State Gas Company located in Jakarta. Stratified Sampling Sample was used and data were analyzed by using Statistical Package for Social Sciences (SPSS). The method used to analyze data were Descriptive Statistic Method and Multiple Regression. From the result of this research, it can be concluded that there was a positive relationship between organizational commitment and transformational leadership, as well as a positive relationship between transformational leadership and job satisfaction.

Keywords: transformational leadership style, job satisfaction, organizational commitment

\begin{abstract}
Abstrak
Tujuan dari penelitian ini adalah untuk menganalisis pengaruh Gaya Kepemimpinan Transformasional terhadap Kepuasan Kerja dan Komitmen Organisasi. Perancangan penelitian menggunakan data primer yang diperoleh dengan menyebarkan kuesioner kepada 147 responden karyawan Perusahaan Gas Negara yang berada di Jakarta. Metode pengambilan sampel menggunakan stratified sampling dan data dianalisis dengan menggunakan SPSS. Data dianalisis menggunakan metode statistik deskriptif dan regresi berganda. Hasil penelitian menyimpulkan bahwa terdapat pengaruh positif antara komitmen organisasional dengan kepemimpinan transformasional, serta pengaruh positif antara kepemimpinan transformasional dan kepuasan kerja.
\end{abstract}

Kata kunci: gaya kepemimpinan transformasional, kepuasan kerja, komitmen organisasi

\section{INTRODUCTION}

Leadership is a frequently studied discussion in organizations, because leadership affects many aspects of each activity. The definition of leadership according to House et al., In Yukl (2009: 4): "Leadership is the ability of individuals to influence, motivate, and make others able to contribute to the effectiveness and success of the organization." Leadership serves as an engine driving force, can also be regarded 
as one of the determinants of corporate success. Good communication exists between the leader and the subordinate will produce a harmonious relationship within the company. Good relationships will create a comfortable feeling for employees. A leader, in addition to the duty to lead and evaluate the performance of his subordinates, should also be a listener for his subordinates who are having problems. As a basic foundation in the establishment of an organization, the role of a leader is crucial in an effort to achieve the goals set. Thus, the authority holder must master the basics of leadership that will be used in an organization. A leader is expected to influence his subordinates in order to achieve his goals without having to ignore the desires of his subordinates.

It has been proven in the literature that the transformational leadership style is a key feature of organizational performance, while job satisfaction and organizational commitment are theoretically and empirically related to organizational effectiveness. There are many different opinions about the relationship between transformational leadership styles, job satisfaction and organizational commitment. Some studies confirm that the relationship between these variables is positive, while other studies show a negative relationship between them. Furthermore, this study was conducted to investigate the relationship between transformational leadership, job satisfaction and organizational commitment, as well as the influence of organizational commitment as a mediating variable on the relationship between leadership style and job satisfaction in the gas sector in Indonesia, the State Gas Company.

Initially, gas procurement in Indonesia was conducted by a private Dutch gas company named I.J.N. Eindhoven \& Co was established in 1859 by introducing the use of made coal gas in Indonesial. The process of power transition took place at the end of World War II in August 1945, when the Japanese surrendered to the allies. This opportunity is utilized by the youth and electric workers through the delegation of Labor / Electrical and Gas Workers who together with the Central KNI Leaders took the initiative to confront the first President of Indonesia, to submit the companies to the Government of Indonesia.

Subsequently, on May 13, 1965, the company was transformed into Perusahaan Gas Negara(PGN). This dateis then commemorated as the anniversary of PGN every year. The company originally drains artificial gas from coal and oil with uneconomical Catalytic Reforming techniques. Then, began replace by natural gas in 1974 in the city of Cirebon. PGN then entering a new phase became an open company marked with the listing of PGN shares on December 15, 2003 on the Indonesia Stock Exchange and its name was officially become PT Perusahaan Gas Negara (Persero) Tbk.

The term transformational leadership style was created by politologist Burns in 1978, and was later developed by Bass and his colleagues Avolio and Yammarino (2002) Bass (1985). Transformational leaders are leaders who motivate followers through inspiration. The followers are offered challenges and support the development of personality. It concentrate, on intangible quality, such as sharing ideas, shared values and vision in an effort to build good relati o nships within the organization Bass (1985). A ccording to Bass, Avolio, Jung and Berson (2003) the dimensions of the transformational leadership style are as follows: a consis tent leader in behavior, ethics, principles, and values. The relationship between leader and subordinate is not based on formal institutional rules, rewards or punishments but it is based on personal understanding. Leaders who emp $\mathrm{h}$ asize a sense of community in carrying out missions and values, and act according to these values (Molero, Cuadrado, Navas and M o rales, 2007). Leaders who motivate an $d$ inspire 
those around them. Leaders who stimulate their subordinate intellect to be innovative and creative in solving various work problems. Leaders who act as trainers or mentors in an effort to improve employee performance.

In the last three decades, academics and researchers have increased their attention to a new paradigm called the transformational leadership style. This style of leadership is widely used in Western and non-Western countries. Suleiman, Azzawi and Jerjer (2003), AL-azmi (2006), and Sabri (2006) explained that the transformational leadership style has been widely used in various sectors in Arab countries such as Iraq, Saudi Arabia, Jordan and the United Arab Emirates. Many other researchers have examined the relationship between variables in different sectors such as the public sector, the health sector, the industrial sector, the service sector, the manufacturing sector and the education sector in Arab and Western countries, where leaders from these sectors follow the leadership style, Transformational, to manage their organization. Suleiman, Azzawi and Jerjer (2003), AL-azmi (2006), Ramey (2002) explain the relationship between transformational leadership styles, job satisfaction, and the impact of organizational commitment on the relationships between those variables. A number of research results in the field of job satisfaction have shown that leadership style and organizational commitment have a significant impact on job satisfaction (Lok\& Crawford 2001; Yousef, 2001; Ramey, 2002). There are studies that focus on comparing the two main aspects of leadership that are transformational and transactional. The study shows that the transformational leadership style has a stronger positive effect on employees that is attitudes toward work, to the work environment and ultimately affect their performance than the transactional leadership style (Bass, 1985) and Burn (1978). Thus, this study would like to test the transformational leadership theory in Perusahaan Gas Negara in Jakarta.

The topics of organizational commitment have become very popular in the last two decades through researchers and practitioners in the field of management (Mowday, et al. 1982; Meyer \& Allen, 1991). Organizational commitment has been studied in various contexts; Including (a) Organizational Support (O "Driscoll \& Randall, 1999), (b) Performance of foreign workers (Shawa, et al., 2003); (c) Work (Wasti, 2005), (d) Innovative Trusts and Behavior (Lee, 2008), (e) Organizational Culture and Leadership Style (Lok\& Crawford, 1999) and (f) Job Satisfaction (Lim, 2010; Shurbagi\&Zahari, 2013b). Some studies show that organizational commitment has positive relationship with these variables.

Organizational commitment, like most other concepts in social science, has no single definition and is defined differently by different authors. For example, Kanter, 1968 describes organizational commitment as a group of individuals' effectiveness and emotions. While Buchanan (1974) describes organizational commitment as partisan that supports the goals and values of the organization above its own interests. According to Porter, et al. (1974), organizational commitment is defined as the strength of the individual within his or her involvement in a particular organization. Such commitment can generally be characterized by at least three factors:

a. Strong belief and acceptance of the organization's goals and values.

b. Willingness to exert sufficient effort on behalf of the organization.

c. Definite desire to maintain organizational membership.

O'Reilly and Chatman (1986) define commitment as the psychological feelings felt by people for organizations, 
reflecting the extent to which individuals adopt organizational characteristics or perspectives. Mathieu and Zajac, (1990) define organizational commitment as "the bond or individual relationship to the organization". On the other hand, Meyer and Allen (1984), Porter, et al. (1974), divide the concept of organizational commitment into three components: affective, continuous, and normative. Affective commitment refers to the emotional attachment of employees, identification and involvement in the organization. The continuity commitment refers to the individual's awareness of not leaving the organization. Normative commitment reflects a feeling of obligation to continue work.

The three components or dimensions of organizational commitment introduced by Meyer and Allen (1984) are rooted in previous approaches by Becker (1960) and Porter, et al. (1974). Meyer and Allen (1984) assert that the three dimensions of commitment that are affective, sustainable and normative are psychological states that describe the nature of employee relationships with the organization, and their implications for the decision to continue or terminate membership in the organization. However, it is clear that the nature of the three psychological states is different, and is described as follows:

a. Affective commitment refers to the emotional attachment of employees to the organization, identification with the organization, and involvement in the organization. Employees with strong affective commitment will continue to work for the organization because of their own desires (Meyer \& Allen, 1984). The most important reason is related to the ability to meet their needs at work (Hackman \& Oldham, 1976). Allen and Meyer (1990) have suggested that antecedents of affective attachment to organizations are divided into four categories: personal characteristics, work characteristics, work experiences and structural characteristics.

b. Continuance Commitment is described by Meyer and Allen (1984) as the sustainability dimension that incudes cost or financial awareness, benefits, and risks when leaving the organization. All the risks that include pension funds, seniority, social status and access to social networks are also explained by Dawleyaet.a.1( 2005) and Shahnawaz\&Juyal ( 2006 ).

c. Normative commitment is defined as an obligation to continue the work. Employees with high levels of normative commitment feel that they must remain in the organization (Allen and Meyer, 1990). Individuals with high normative commitment believe that the obligation to stay with the organization is a moral thing to do where they will feel guilty if they leave the organization (Felfea\& Yan, 2009). Normative commitment is strongly influenced by socio-culture and good life in families and organizations (Wiener, 1982; Cohen, 2007).

The three dimensions of commitment are also explained by Wiener (1982) and Kohen (2007), and Weibo et al (2010).

Job satisfaction has become an intriguing and intense phenomenon discussed by practitioners and researchers for several decades (Cranny, et al. 1992; Hwang \& Chi, 2005; Locke, 1976; Spector, 1997). Many different definitions, for example some focus on the work itself, while others focus on all work-related factors. Some practitioners and researchers define satisfaction as positive feelings or aggressive responses; While other practitioners and researchers define it as a gap between what is obtained and what is expected. According to Spector (1985), job satisfaction is a group of evaluative feelings about work.

According to the literature on job 
satisfaction, there are many factors that affect job satisfaction (Worrell, 2004), against three groups of demographic data covering age, sex, and race ie intrinsic factors that include achievement, recognition, responsibility, progress and growth, and extrinsic factors that include company policy, supervision, relationships with the Boss, working conditions, peer relations and salary. These two factors are related to The Herzberg Two Factor Theory (Herzberg, 1966).

In the last three decades, academics and researchers have raised concerns to investigate the relationship between leadership behaviors, job satisfaction, and organizational commitment, and most of these studies have examined the relationship between these variables independently (Williams \&Hazar, 1986; Yousef, 2000 ;Lok\& Crawford, 2001; Lim, 2010). Many of the studies in the field of organizational behavior confirm that the relationship between transformational leadership styles, job satisfaction and organizational Commitment is a significant and positive relationship (Yousef, 1998; Chen\&Francesco, 2000; Lok\&Crawford 2001; Xenikou\&Simosi; 2006; Yarmohammadian, 2006, Hu, et al., 2009; Shurbagi\&Zahari, 2012b).

On the other hand, Yiing and Zaman Ahmad, (2009), show a negative relationship between job satisfaction and organizational commitment in the Education sector in Malaysia. Yousoef (2000) and Lim (2010) further stated that job satisfaction and organizational commitment are theoretically and empirically related to organizational effectiveness. Lok and Crawford (2004) assert that organizational commitment and job satisfaction can be a major determinant of organizational performance and effectiveness. In addition, Oluseyi and Ayo (2009) explain that leadership is central to the Feature of organizational performance and an important part of people management activities and the direction of their efforts towards the goals and objectives of the organization.

Perryer and Jordan (2005) assert that organizational commitment is an important employee attribute within the organizational perspective. Several studies have found an association between high human resource policies, organizational commitment and positive organizational outcomes such as productivity, quality, and profitability. Organizational commitment has been studied in relation to employee performance and there is some evidence to show that organizational commitment is a mediating variable between leadership and performance styles.

Briefly, some scholars have examined the mediation and impact of moderation of organizational culture and organizational commitment on the relationship between leadership behaviors, work performance and job satisfaction. For example, Chen (2004) asserts that the influence of leadership behavior on organizational commitment will differ from organizational culture. Therefore, organizational commitment as a mediation effort in the relationship between transformational leadership behaviors and job satisfaction is found not to be influenced by organizational culture. These findings confirm that organizational commitment mediates the relationship between transformational leadership styles and work performance. Furthermore, Lok and Crawford, (2004) reveal that organizational commitment and job satisfaction are influenced by different types of organizational culture, while leadership styles may impact on job satisfaction and commitment. Also Crawford (2004) have confirmed that organizational culture and leadership style are important antecedents of job satisfaction and commitment.

On the other hand, Yiing and Zaman Ahmad (2009) examine the moderating effects of organizational culture on the relationship between leadership behaviors and organizational commitment and 
between organizational commitment and job satisfaction and performance. Yiing and ZamanAhmad(2009)show thatorganizational culture has a significant moderation effect on the relationship between leadership behaviors and organizational commitment while the relationship between job satisfaction and organizational commitment is a negatively significant relationship. However, the effect of organizational commitment as a mediating variable on the relationship between transformational leadership styles and job satisfaction is not explored quite intensively in the literature in general and, in the petroleum sector particulary. Consequently, studies that examine the complex relationships and interactions between variables such as transformational leadership styles, job satisfaction and organizational commitment and the influence of organizational commitment on these relationships will be valuable to management and practitioner theory. Furthermore, this study would like to examine the relationship between transformational leadership style, job satisfaction, organizational commitment and the influence of organizational commitment on this relationship at Perusahaan Gas Negara in Jakarta.

Based on the literature review, the hypothesis formulation is as follows:

H1: There is a relationship between transformational leadership styles and job satisfaction at State Gas Company in Jakarta.

$\mathrm{H} 2$ : There is a relationship between transformational leadership styles and organizational commitment at State Gas Company in Jakarta.

H3: There is a relationship between job satisfaction and organizational commitment in State Gas company in Jakarta.

H4: Orgnizational commitment has a significant influence on the relationship between transformational leadership style and job satisfaction in the State Gas Company in Jakarta.

Based on the background and formulation of the above problems, the purpose of this study can be formulated as follows:

1. Determine the nature of the relationship between the transformational leadership style and job satisfaction in the State Gas Company in Jakarta.

2. Determine the nature of the relationship between transformational leadership styles and organizational commitment in Perusahaan Gas Negara in Jakarta.

3. Determine the nature of the relationship between job satisfaction and organizational commitment in Perusahaan Gas Negara in Jakarta.

4. Determine the influence of organizational commitment on the relationship between transformational leadership style and job satisfaction in Perusahaan Gas Negara in Jakarta.

\section{METHOD}

In this study, to collect data, we used questionnaires consisting of four parts, namely demographic variables, transformational leadership style, job satisfaction, and organizational commitment. The three instruments used to measure research variables are:

1. Multifactor Leadership Questionnaire (MLQ) is used to measure transformational leadership styles (Avolio and Bass, 2004). This instrument has been revised several times and is widely used to measure transformational leadership styles in various countries of the world and the validity and reliability of this scale has been established through 
previous research (Hartog, Muijen and Koopman, 1997). Participants were asked to describe their superior leadership behaviors on 16 items based on transformational leadership. Five points of Likert scale are used with responses ranging from $(1=$ strongly disagree, to $5=$ strongly agree). In (MLQ) the transformational leadership style is measured through the use of three dimensional transformational leadership styles.

2. Three Components of Organizational Commitment Questionnaire(TCOCQ) developed by Allen and Meyer (1990) are used to measure organizational commitment. The instrument measures three dimensions of organizational commitment including items that measure affective, continuance and normative commitment. There are 12 items in the scale of each dimension of organizational commitment (affective, continuous and normative). The five point Likert scale is used with responses ranging from $(1=$ strongly disagree, to $5=$ strongly agree)

3. Job Satisfaction Survey (JSS) developed by Spector (1997) that includes 3 items is used to measure job satisfaction. The five point Likert scale is used with responses ranging from $(1=$ strongly disagree, to $5=$ strongly agree). Therefore, the validity and reliability of the instruments used in this study such as the Multifactor Leadership Questionnaire (MLQ), Job Satisfaction Survey (JSS) and Three Components of Organizational Commitment Questioonaire (TCOCQ) have been established through previous researchers, The Cronbach's Alpha coefficients of the instrument are above 0.70 (Allen \& Meyer, 1990; Spector, 1997; Lim, 2010; Shurbagi\&Zahari, 2013b; Shurbagi, 2014a).
To know the effect of organizational commitment to the relationship between Transformational leadership style and job satisfaction at Perusahaan Gas Negara in Jakarta, as many as 147 participants fill out the questionnaire. Stratified Sampling Sample was used in this study and data were analyzed with Statistical Package for Social Sciences (SPSS).

\section{RESULT AND DISCUSSION}

Data were analyzed by descriptive statistic method and Multiple Regression. From the questionnaires it can be seen clearly that the respondents between 36-45 years old are the majority of respondents as many as 48 people $(32.7 \%)$ of the total respondents, while the least are respondents with age range above 55 years as many as 3 people $(2 \%)$. As mentioned earlier, respondents for this research are employees at Perusahaan Gas Negara in Jakarta. The majority of respondents hold Bachelor degree as many as 85 people $(57.8 \%)$, while 26 respondents $(17.7 \%)$ complete their postgraduate degree. $125(86.2 \%)$ of the respondents were married while only 20 respondents $(13.8 \%)$ were unmarried. Of the total 147 respondents from Perusahaan Gas Negara in Jakarta showed that, 120 of them $(81.6 \%)$ reported that their income was more than Rp9.000.000,00. And 14 respondents $(9.5 \%)$ reported that their income was between $\operatorname{Rp} 7,000,000.00$ to Rp9,000,000.00 and only three respondents $(2 \%)$ their salary between Rp3,000,000.00 to Rp5,000,000.00. It can be seen that 38 respondents $(25.9 \%)$ have experience working with Perusahaan Gas Negara in Jakarta for 6-10 years, and only 10 respondents $(6.8 \%)$ have experience working in Perusahaan Gas Negara in Jakarta for 1-5 years . The majority of respondents of $113(76.9 \%)$ had bosses as coordinators, followed by 23 respondents $(15.6 \%)$ had bosses as directors, and the remaining only 11 respondents $(7.5 \%)$ whose boss function was observers. 
The following will discuss mean, standard deviation of transformational leadership dimensions.

Table 1 provides an overview of the percentages, mean, and standard deviations associated with perceptions of respondents from Perusahaan Gas Negara in Jakarta on transformational leadership, job satisfaction and organizational commitment in their organizations. According to Table 1 , the means of transformational leadership dimensions such as idealized influence,

Table 1. Mean and Standard Deviation of Transformation Leadership Dimensions

\begin{tabular}{|c|c|c|}
\hline Variable & Mean & $\begin{array}{l}\text { Standard } \\
\text { Deviation }\end{array}$ \\
\hline Idealized Influence & 3,7296 & 0,73836 \\
\hline Leaders instill a sense of pride in themselves & 3,4626 & 0,95997 \\
\hline Leaders always prioritize the interests of the organization rather than personal interests. & 3,6054 & 1,03737 \\
\hline Leaders always encourage me to do the job well. & 3,9048 & 0,88622 \\
\hline Leaders show confidence & 3,8095 & 0,87063 \\
\hline Leaders always express the importance of value and confidence in the work. & 3,8095 & 0,93144 \\
\hline Leadership shows the importance of having confidence to achieve the goal. & 3,8299 & 0,87878 \\
\hline Leaders always consider the ethical and moral consequences of making decisions. & 3,7415 & 0,88433 \\
\hline The chairman of the meeting emphasized the importance of joint decision-making on a problem. & 3,6735 & 0,77780 \\
\hline Inspirational Motivation & 3,6990 & 0,78837 \\
\hline Leaders always speak optimistically about the future. & 3,6939 & 0,86870 \\
\hline Leaders are always encouraging about what needs to be done in work. & 3,7415 & 0,88354 \\
\hline Leaders always assert the achievement of the company's vision. & 3,6803 & 0,85996 \\
\hline Leaders always assure me that I will achieve the goals of the company. & 3,6803 & 0,86870 \\
\hline Intellectual Stimulation & 3,6304 & 0,82680 \\
\hline Leaders encourage me to look at different ways of solving problems. & 3,6667 & 0,84670 \\
\hline Leaders encourage me to look at issues from all sides. & 3,7279 & 0,91080 \\
\hline Leaders showed me new ways to get things done. & 3,4966 & 1,02285 \\
\hline Affective Commitment & 3,5737 & 0,74309 \\
\hline I do not feel like being a "family member" of this organization. & 3,4354 & 0,96563 \\
\hline This organization has a personal meaning to me. & 3,5034 & 0,92436 \\
\hline Emotionally I do not feel part of this organization. & 3,7823 & 0,85622 \\
\hline \multicolumn{3}{|l|}{ I have a strong sense of belonging to the organization } \\
\hline Commitment Continues & 3,4983 & 0,77884 \\
\hline It's very difficult for me to leave this organization, I want to. & 3,6054 & 0,95486 \\
\hline One option of this organization is the possibility of scarcity of alternatives. & 3,8095 & 0,87846 \\
\hline One of the main reasons I settled in this organization was because taking care of this job would hurt me. & 3,4082 & 0,98450 \\
\hline For me, working in this organization is a need and a desire. & 3,1701 & 1,04929 \\
\hline Normative Commitment & 3,3673 & 0,79452 \\
\hline Switching from one place to another is a natural thing for me. & 3,1361 & 1,05752 \\
\hline I do not agree if someone should always be loyal to the organization. & 3,2993 & 1,08801 \\
\hline In my opinion, there are times when someone moves from one company to another. & 3,6667 & 0,86272 \\
\hline Job satisfaction & 3,3537 & 0,85049 \\
\hline I am satisfied with my current job. & 3,2041 & 1,12225 \\
\hline My work environment is fun. & 3,0952 & 1,11240 \\
\hline I am very happy because I work in this company, not elsewhere. & 3,7619 & 0,95324 \\
\hline
\end{tabular}

Source : results of data processing (2017) 
inspirational motivation, and intellectual motivation have mean 3,7296, 3,6990 and 3,6304 and their standard deviations are $0.73836,0.78837$ and 0.82680 . On the other hand, according to table 1, affective commitment, ongoing commitments and normative commitments have mean respectively $3.5737,3.4983$ and 3.3673 , while the standard deviations of them are $0.74309,0.77884$ and 0.79452 . The last variable, the aspect of job satisfaction has a mean of 3.3537 and a standard deviation of 0.85049 . Table 1 summarizes the mean and standard deviations of these variables.

Cronbach Alpha coefficient is used to test the reliability of the instruments of Sekaran (2005). It shows that Cronbach Alpha Coefficient of 0.70 or more is considered good. Cronbach's alpha reliability coefficients for transformational leadership are divided into three namely idealized influenced, inspirational motivation and intellectual motivation, the results are 0.9277 , 0.9115 and 0.8679 respectively.

Cronbach's Alfa for organizational commitment is divided into affective commitment, ongoing commitments and normative commitments are $0.7394,0.8176$ and 0.6957. While Cronbach's Alpha for job satisfaction is 0.7153.Base on Cronbach Alpha value for transformational leadership, organizational commitment and job satisfaction, then the instrument can be relied upon to measure the research variable. Following in table 2 will discuss validity and relaibility with the details:

Table 2. Data Validity and Data Reliability

\begin{tabular}{lc}
\hline \multicolumn{1}{c}{ Variable } & Cronbach's Alpha \\
\hline Idealized Influence & 0,9277 \\
Inspirational Motivation & 0,9115 \\
Intellectual Stimulation & 0,8679 \\
Affective Commitment & 0,7394 \\
Continuance Commitment & 0,8176 \\
Normative Commitment & 0,6957 \\
Job satisfaction & 0,7153 \\
\hline
\end{tabular}

To study the relationship between variables, the Spearman correlation coefficient was chosen to investigate the relationship between these variables. Table 3 below shows that there is a high and significant correlation between the research variables. A weak correlation between transformational leadership styles and job satisfaction is 0.049 and significant at the 0.01 level. A strong relationship has been identified between the transformational leadership style and organizational commitment with a significant correlation coefficient of 0.598 at the 0.01 level. Furthermore, the weak correlation between job satisfaction and organizational commitment is 0.007 at the same level of significance. Table 3 summarizes the correlation between research variables.

Tabel 3. Correlation Between Research Variables

\begin{tabular}{lccc}
\hline & $\begin{array}{c}\text { Transformational } \\
\text { Leadership Job } \\
\text { Satisfaction } \\
\text { Organizational } \\
\text { Commitment }\end{array}$ & $\begin{array}{c}\text { Transformational } \\
\text { Leadership Job } \\
\text { Satisfaction } \\
\text { Organizational } \\
\text { Commitment }\end{array}$ & $\begin{array}{c}\text { Transformational } \\
\text { Leadership Job } \\
\text { Satisfaction } \\
\text { Organizational } \\
\text { Commitment }\end{array}$ \\
\hline $\begin{array}{l}\text { Transformational } \\
\text { leadership }\end{array}$ & 1 & $0,049^{* *}$ & $0,598^{* *}$ \\
$\begin{array}{l}\text { Job satisfaction } \\
\text { Organizational } \\
\text { Commitment }\end{array}$ & 1 & $0,007^{* *}$ \\
\hline
\end{tabular}

*** Correlation is significant at the 0,01 level (one tail)

Source: results of data processing (2017) 
Based on table 4, the correlation between the dimension of transformational leadership style, job satisfaction and organization commitment component is positive and significant at the 0.01 level. The highest correlation was found between the dimensions of the transformational leadership style and the job satisfaction aspect in which $r$ $=0.158$ and the lowest correlation was found between job satisfaction and inspirational motivation where $r=0.155$. In addition, the highest correlation between job satisfaction and organizational commitment was found between satisfaction with work environment and normative commitment where $r=0.105$ and the lowest correlation between them was found between job satisfaction in the firm and normative commitment where $r=0.083$.

On the otherhand, thehighest correlation between the transformational leadership style dimension and organizational commitment component was found between idealized influencing and affective commitment, $\mathrm{r}=$ 0.576 and the lowest correlation was found between idealized influencing and normative commitment, $r=0.333$.

Table 4. Correlation Between Variable Dimension

\begin{tabular}{lcc}
\hline \multicolumn{1}{c}{ Variable } & $\begin{array}{c}\text { Pearson } \\
\text { Correlation }\end{array}$ & Sig (1- tailed) \\
\hline Idealized Influence -Inspirational Motivation & 0,804 & 0,000 \\
Idealized Influence - Intellectual Stimulation & 0.675 & 0,000 \\
Idealized Influence - Affective Commitment & 0,576 & 0,000 \\
Idealized Influence - Continuance Commitment & 0,401 & 0,000 \\
Idealized Influence -Normative Commitment & 0,333 & 0,000 \\
Idealized Influence - Job Satisfaction & 0,240 & 0,388 \\
& & \\
Inspirational Motivation - Intellectual Stimulation & 0,655 & 0,000 \\
Inspirational Motivation - Affective Commitment & 0,528 & 0,000 \\
Inspirational Motivation - Continuance Commitment & 0,450 & 0,000 \\
Inspirational Motivation -Normative Commitment & 0,387 & 0,000 \\
Inspirational Motivation - Jobb Satisfaction & 0,008 & 0,462 \\
& & \\
Intellectual Stimulation - Affective Commitment & 0,465 & 0,000 \\
Intellectual Stimulation - Continuance Commitment & 0,456 & 0,000 \\
Intellectual Stimulation -Normative Commitment & 0,370 & 0,000 \\
Intellectual Stimulation - Job Satisfaction & 0,040 & 0,315 \\
& & \\
Affective Commitment - Continuance Commitment & 0,597 & 0,000 \\
Affective Commitment -Normative Commitment & 0,426 & 0,000 \\
Affective Commitment - Job Satisfaction & 0,039 & 0,318 \\
Continuence Commitment -Normative Commitment & & \\
Affective Commitment - Job Satisfaction & 0,489 & 0,000 \\
Normative Commitment - Job Satisfaction & $-0,021$ & 0,000 \\
\hline & & 0,378 \\
\hline
\end{tabular}

Source:Resource data processing (2017) 
Based on the results of correlation analysis between research variables and dimensions, it can be concluded that the relationship between variables of transformational leadership style, job satisfaction and organizational commitment is a significant positive relationship. In addition, these results are consistent with previous studies which concluded that the relationship between transformational leadership styles, job satisfaction and organizational commitment is a positive and significant relationship. The following is Table 4 which summarizes the results of variable dimension correlations.

To examine the effect of organizational commitment on the relationship between transformational leadership and job satisfaction at Perusahaan Gas Negara in Jakarta, multiple linear regression analysis was used. As shown in Table 5, R Square 0.003 The probability value obtained is less than that specified, ie the alpha value (p-value <0.05). There is evidence to suggest that organizational commitment has no significant effect on the relationship between transformational leadership and job satisfaction at Perusahaan Gas Negara in Jakarta. In addition, organizational commitment has no significant effect on the relationship between transformational leadership styles and job satisfaction. From the results of regression analysis can be concluded that organizational commitment does not affect the relationship between transformational leadership style and job satisfaction. Table 5 summarizes the results of multiple regression analysis.

Table 5. Multiple Regression Analysis Between Research Variables

\begin{tabular}{cccc}
\hline $\mathbf{R}$ & $\begin{array}{c}\mathbf{R} \\
\text { Square }\end{array}$ & $\begin{array}{c}\text { Adjusted } \mathbf{R} \\
\text { Square }\end{array}$ & $\begin{array}{c}\text { Std. Error of } \\
\text { the Estimate }\end{array}$ \\
\hline 0,056 & 0,003 & $-0,011$ & 0,85502 \\
\hline
\end{tabular}

Source: results of data processing (2017)

\section{CONCLUSION}

This research has tried to explain the relationship between transformational leadership, job satisfaction and organizational commitment and the influence of organizational commitmenton the relationship between transformational leadership and job satisfaction in Perusahaan Gas Negara in Jakarta. It was found that there is a positive relationship between organizational commitment and transformational leadership, as well as a positive relationship between transformational leadership and job satisfaction. The results of this study are largely consistent with prior research, except for the results of the effects of organizational commitment that are not explored in the literature. There are limitations in research design, such as other leadership styles, namely transactional, and laissez-faire that are unexplored because these variables may also have a relationship to job satisfaction and organizational commitment.

In addition, the results of leaders in this study are not included within the scope of this study where these factors may have a relationship to job satisfaction and organizational commitment and may have an effect on the performance of organizations in the public and private sectors. Therefore, further studies are suggested using other leadership styles so that leaders can fully understand and appreciate appropriate methodologies that will be effective for improving performance within a particular public sector organization. In addition, it is recommended that similar research be conducted in the private sector or in both, public and private sectors to determine whether the relationship between transformational leadership, job satisfaction and organizational commitment varies across sectors. This can help to clarify the differences between the public and private sectors. This study was conducted in a small geographical area and this may have 
influenced the validity of generalizations. In subsequent research may require a wider scope. Similarly, the results of the leaders in this study are not within the scope of this study. Therefore, future researchers can investigate the outcomes of leaders in both the public and private sectors.

\section{REFERENCES}

Bass, B. M. 1985. Leadership: Good, better, best. OrganizationalDynamics, 13(3), 26-40. https://doi.org/10.1016/00902616(85)90028-2

Bass, B. M., Avolio, B. J., Jung, D. I., \& Berson, Y. 2003. Predicting unit performance by assessing transformational and transactional leadership. The Journal of Applied Psychology, 88(2), 207-218. https:// doi.org/10.1037/0021-9010.88.2.207

Buchanan, B. 1974. Building organisational commitment: the socialisation of managers in work organisations. Administrative Science Quarterly, 19(4), 533-546. https://doi. org/10.2307/2391809

Chen, L.Y. 2004. Examining the effect of organization culture and leadership behaviors on organizational commitment, job satisfaction, and job performance at small and middlesized firms of Taiwan, Journal of American Academy of Business, Vol. 5, No. 1/2, pp. 432-8.

Dawley, D. D., Stephens, R. D., \& Stephens, D. B. 2005. Dimensionality of organizational commitment in volunteer workers: Chamber of commerce board members and role fulfillment. Journal of Vocational Behavior, 67(3), 511-525. https:// doi.org/10.1016/j.jvb.2004.09.001

den Hartog, D. N., van Muijen, J. J., \& Koopman, P. L. 1997. Transactional versus transformational leadership: An analysis of the MLQ. Journal of Occupational and Organizational Psychology, 70(1997), 19-34. https:// doi.org/10.1111/j.2044-8325.1997. tb00628.x

Dutton, J. E., Dukerich, J. M., \& Harquail, C. V. 1994. Organizational Images and Member Identification. Administrative Science Quarterly, 39(2), 239-263. https://doi. org $/ 10.2307 / 2393235$

Dvir, T., Eden, D., Avolio, B. J., \& Shamir, B. 2002. Impact of Transformational Leadership on Follower Development and Performance: A Field Experiment. The Academy of Management Journal, 45(4), 735744. https://doi.org/10.2307/3069307

Hackman, J. R., \& Oldham, G. R. 1976. Motivation through the design of work: test of a theory. Organizational Behavior and Human Performance, 16(2), 250-279. https://doi. org/10.1016/0030-5073(76)90016-7

Herzberg, Frederick. 1966. Work and the Nature of Man. Cleveland: World Publishing. OCLC 243610

Lee, S. H. 2008. The effect of employee trust and commitment on innovative behavior in the public sector: An empirical study. International Review of Public Administration, 13(1), 2746. https://doi.org/10.1080/1229465 9.2008.10805110

Lok, P., \& Crawford, J. 1999. The relationship between commitment and organizational culture, subculture, leadership style and job satisfaction in organizational change and development. Leadership \& Organization Developmental Journal, 20(7), 365-374. https://doi. org/10.1108/01437739910302524

Lok, P., \& Crawford, J. 2001. Antecedents of 
Organizational Commitment and the Mediating Role of Job Satisfaction. Journal of Managerial Psychology, 16(8), 594-613. https://doi. org/10.1108/EUM0000000006302

Lok, P., \& Crawford, J. 2004. The effect of organisational culture and leadership style on job satisfaction and organisational commitment: A cross-national comparison. Journal of Management Development, 23(4), 321-338. https://doi. org/10.1108/02621710410529785

Mathieu, J., \& Zajac, D. 1990. A review and meta-analysis of the antecedents, correlates, and consequences of organizational commitment. Psychological Bulletin, 108(2), 171194. https://doi.org/10.1037/00332909.108.2.171

Molero, F., Cuadrado, I., Navas, M., \& Morales, J. F. 2007. Relations and effects of transformational leadership: A comparative analysis with traditional leadership styles. The Spanish Journal of Psychology, 10(2), 358-368. https://doi.org/10.1017/ S1138741600006624

O’Driscoll, M., \& Randall, D. 1999. Perceived organisational support, satisfaction with rewards, and employee job involvement and organisational commitment. Applied Psychology, 48(2), 197-209. https:// doi.org/10.1111/j.1464-0597.1999. tb00058.x

Perks, K. J., Hogan, S. P., \& Shukla, P. 2013. The effect of multi-level factors on MNEs' market entry success in a small emerging market. Asia Pacific Journal of Marketing and Logistics, 25(1), 131-143. https://doi.org/http://dx.doi. org/10.1108/13555851311290975

Perryer, C., \& Jordan, C. 2005. The influence of leader behaviors on organizational commitment: A study in the Australian public sector. International Journal of Public Administration, 28(February 2015), 379-396. https://doi.org/10.1081/ PAD-200055193

Porter, L. W., Steers, R. M., Mowday, R. T., \& Boulian, P. V. 1974. Organizational commitment, job satisfaction, and turnover among psychiatric technicians. Journal of Applied Psychology, 59(5), 603-609. https:// doi.org/10.1037/h0037335

Shaw, J. D., Delery, J. E., \& Abdulla, M. H. A. 2003. Organizational commitment and performance among guest workers and citizens of an Arab country. Journal of Business Research, 56(12), 10211030. https://doi.org/10.1016/S01482963(01)00316-2

Society, A. 2014. Government Managers, Business Commitment Organizational, 34(4), 339-347.

Spector, P. E. 1997. Job satisfaction: Application, assessment, causes, and consequences. Thousand Oaks, CA.:Sage.

Spector, P. E. 1985. Spector, Paul E., Measurement of Human Service Staff Satisfaction: Development of the Job Satisfaction Survey. American Journal of Community Psychology, 13(6), 693. https://doi.org/10.1007/ BF00929796

Wasti Arzu, S. 2005. Commitment profiles: Combinations of organizational commitment forms and job outcomes. Journal of Vocational Behavior, 67(2), 290-308. https:// doi.org/10.1016/j.jvb.2004.07.002

Weibo, Z., Kaur, S., \& Jun, W. 2010. New Development of Organizational Commitment: A Critical Review 
(1960 - 2009). African Journal of Business Management, 4(1), 12-20.

Williams, L. J., \& Hazer, J. T. 1986. Antecedents and consequences of satisfaction and commitment in turnover models: A reanalysis using latent variable structural equation methods. Journal of Applied Psychology, 71(2), 219-231. https:// doi.org/10.1037/0021-9010.71.2.219

Yiing, L. H., \& Ahmad, K. Z. Bin. 2009. The moderating effects of organizational culture on the relationships between leadership behaviour and organizational commitment and between organizational commitment and job satisfaction and performance.
Leadership \& Organization Development Journal, 30(1), 5386. https://doi.org/http://dx.doi. org/10.1108/JEIM-07-2014-0077

Yousef, \& a., D. 2000. Organizational commitment: a mediator of the relationships of leadership behavior with job satisfaction and performance in a non-western country. Journal of Managerial Psychology, 15(1), 6-24. https://doi. org/10.1108/02683940010305270

Yukl, G. 2009. Leading organizational learning: Reflections on theory and research. Leadership Quarterly, 20(1), 49-53. https://doi. org/10.1016/j.leaqua.2008.11.00 